Article

\title{
Government Governance, Legal Environment and Sustainable Economic Development
}

\author{
Feng Wei ${ }^{1, *}$ and Yu Kong ${ }^{2}$
}

1 School of Economics and Business Administration, Chongqing University, No. 174 Shazhengjie, Shapingba District, Chongqing 400030, China

2 College of Economics, Guizhou University, Huaxi District, Guizhou Province, 550025 Guiyang, China; E-Mail: ca.ykong@gzu.edu.cn

* Author to whom correspondence should be addressed; E-Mail: wfmx@cqu.edu.cn; Tel.: +86-139-9612-2668; Fax: +86-23-6536-7768.

Received: 29 January 2014; in revised form: 7 April 2014 / Accepted: 8 April 2014 /

Published: 16 April 2014

\begin{abstract}
Based on China's inter-provincial panel data from 1999-2009, this paper has tested the impact and extent of marketization, government governance, and legal environment of sustainable economic development by controlling physical capital, human capital and productivity, so as to find the institutional reality for the difference in China's economic development and another explanation for it. It turns out that marketization, government governance, and legal environment play significant roles in promoting sustainable economic development. Further tests show that the results of Eastern China are consistent with China's inter-provincial results; while in Western China, the promotion effect of marketization, government governance, and legal environment on sustainable economic development is not significant.
\end{abstract}

Keywords: government governance; legal environment; sustainable economic development

\section{Introduction}

Since the reform and opening up in 1978, China has attained a consecutively rapid development in economy over 30 years. Are there any reasons to explain China's economic achievements after implementing the reform and opening up policy? Or what factors play key roles in sustainable economic growth in China? Meanwhile, what are the reasons for the disparity of regional 
development? Scholars have given different answers by different empirical data and from different perspectives [1-4]. However, as [5] claims in The Mystery of Economic Growth, economists have conducted some fruitful researches on economic growth since the time of Adam Smith, but till now, it is still a mystery to them why there will be sustainable growth in economy and other related issues.

In growth theory based on neoclassical economic theory, the most important factors for boosting economic growth are labor, capital and technological advance [6,7]; but in new growth theory, the most important factors are technological advance and human capital [8,9]. The development of new institutional economics provides a new way to explain the imbalance of economic development and the difference in productivity. [10-12] analyze the institution's impact on economic output by theoretical deduction and conduct an empirical analysis on the importance of institutional arrangements and institutional structures on the optimization of economic output and individual behavior. Since then, many scholars have conducted empirical researches on the extent of the impact on sustainable economic growth from different institutional perspectives, including private property rights [13,14], market operation [15], inequality and social conflicts [16,17] and government efficiency and corruption [18]. Further, [19,20] believes that economic growth depends on an effective institution, which could effectively restrain government, facilitate technological advancement and capital accumulation, thereby promoting economic growth. However, these studies focus on the national economy as a unit instead of institutional differences in a country. In a unitary state with fixed institutional, cultural and historical backgrounds, this may be negligible, while the differences of the specific institutions in regions could have a more targeted impact on economic growth.

This paper has tested the impact and degree of marketization, government governance, and legal environment on sustainable economic development by controlling physical capital, human capital and productivity, so as to find institutional reality for the difference in China's economic development and an alternative explanation for it. Herein lie the differences between this paper and other existing literatures: first, the measurement on institution variable is different from previous literatures, some of which merely survey marketization [21], or the impact of the property institution which is measured by the ratio of the gross output value of non-state-owned industrial enterprises in the gross industrial output value on sustainable economic growth without considering the impact of government governance and legal environment [22]. On the basis of consecutive and objective institutional measurement index - indexes from Fan et al. [23] - this paper analyzes the impact of government governance and legal environment on sustainable economic development; second, most of the existing literatures analyze the impact of the institution on sustainable economic development from the perspective of inter-provincial panel data, without considering the variables from the perspective of regions. In fact, due to the difference in history and reality, different institutional characteristics are shown in the Eastern Coastal Region and Midwestern Region, and the impact of these characteristics is different. Therefore, some significant results may be ignored in the analysis which is only based on the national or provincial panel data. Third, existing literatures have not controlled the endogeneity of institution, which has become a trend in researching the impact of institution on economic growth now $[24,25]$. On the basis of the existing literatures, the enrollment ratio of secondary school is used as an instrumental variable in this paper, which adds more credibility to the results. 


\section{Study Design}

\subsection{Model and Variables}

The main factors for sustainable economic development include: factor accumulation, productivity, and basic factor [26]. Factor accumulation is comprised of physical capital and human capital; productivity mainly refers to total factor productivity, the increase in output results from technological advance except for capital and labor input; basic factor mainly refers to the government's role in sustainable economic development and the construction of the legal system. Based on this, a model as follows is designed for testing:

$$
\ln y_{i, t}=\alpha+\beta_{1} I_{i, t}+\sum_{i=1}^{3} \beta_{i} \text { control }+\varepsilon
$$

In this model, $y_{i, t}$ is the real GDP of region $i$ in $t$ years, which is calculated by the constant price of 1997; $I_{i, t}$ is the index for the institutional improvement of region $\mathrm{i}$ in $\mathrm{t}$ years. This paper focuses on the impact of government governance and legal environment on sustainable economic development. Marketization, the relationship between government and market, development of market intermediaries and the legal environment by [23] are used to survey the vicissitude of institutional environment, government governance and legal system. These index have been widely used in the literature (e.g., [27,28]) to measure China's regional institutional development, government governance and legal system. Among them, the marketization index captures the following aspects of regional market development: (1) relationship between government and markets, including five sub-index: proportion of economic resources allocated through markets, tax and charge burden on farmers, government's excessive administrative intervention in enterprises, enterprises' nontax burden and excessive size of government. (2) development of non-state sectors, including three sub-index: proportion of the non-state sector in gross industrial output, proportion of the non-state sector in national investment in fixed assets and proportion of the non-state sector in number of employed persons. (3) development of product markets, including two sub-index: percentage of products with market-regulated prices and degree of local protectionism. (4) development of factor markets, including four sub-index: development of the financial market, degree of absorption of foreign investment, liquidity of the labor force and transactions of local technology market weighted by number of technicians. (5) development of market intermediaries and the legal environment, including four sub-index: development of market intermediaries, protection of producers' lawful rights and interests, protection of intellectual property rights, protection of consumers' interests. According to the theme of this paper, we focus on three indexes and their sub-index: marketization, relationship between government and markets and development of market intermediaries and the legal environment. control is the control variable, and according to the existing literatures, it mainly includes natural logarithm of physical capital stock $\ln k_{i, t}$, natural logarithm of human capital stock $\ln h_{i, t}$ and productivity $T F P_{i, t}$. Among which, $K_{i, t}$ is the physical capital stock of region $\mathrm{i}$ in $\mathrm{t}$ years calculated from the formula $K_{i, t}=K_{i . t-1}(1-0.096)+I_{i, t}$ according to the method of Zhang et al. [29]; $K_{i, t-1}$ is the physical capital stock of region $\mathrm{i}$ in t-1years, initial capital stock is the physical capital stock of 1999, which is calculated by constant price of 1997. $I_{i, t}$ is investment volume of fixed capital, 
which is calculated by the constant price of 1997 , and the rate of depreciation is $9.6 \%$. $h_{i, t}$ is the human capital stock of region $\mathrm{i}$ in $\mathrm{t}$ years, which is calculated by labor force's average years of education multiplied by the number of employees, which leads to the formula that labor force's average years of education equals illiteracy $\times 0$ plus primary school $\times 6$ plus junior high school $\times 9$ plus senior high school $\times 12$ plus junior college $\times 15$ plus college $\times 16 . T F P_{i, t}$ is the total factor productivity of region i in $\mathrm{t}$ years, which is calculated according to the method of Zhang and Shi [30], namely, TFP $_{i, t}=Y_{i, t} /\left(K_{i, t}^{0.609} \times L_{i, t}^{0.391}\right)$.

In this paper, the number of employees and labor force's average years of education are derived from the China Labor Statistical Yearbook; institutional variables from Annual Report 2011: Marketization Index for China's Provinces; and other data from Annual Data of China Regional Economy Database in China Stock Market and Accounting Research Database(CSMAR), this database is prepared by the China Accounting and Finance Research Center of the Hong Kong Polytechnic University and the Shenzhen GTA Information Technology Company limited. The period that has been surveyed is 1999-2009. Although the indexes designed by Fan et al. [23] start from 1997, this paper, however, only analyzes the 1999-2009 data to find out the impact of government governance and legal environment on sustainable economic development because the data of 1997 and 1998 are incomplete in many provinces. Meanwhile, because of the obvious regional disparity of Chinese economic development, the paper divides the 31 provinces, municipality, autonomous region in China into Eastern region, Middle region and Western region according to their economic development level. Among them, Eastern region includes Beijing, Tianjin, Hebei, Liaoning, Shanghai, Jiangsu, Zhejiang, Fujian, Shandong, Guangdong and Hainan, Middle region includes Shanxi, Jilin, Heilongjiang, Anhui, Jiangxi, Henan, Hunan and Hubei, Western region includes Inner Mongolia, Guangxi, Guizhou, Yunnan, Shaanxi, Gansu, Qinghai, Ningxia, Xinjiang, Sichuan and Chongqing (exclude Tibet because of data limit).

In light of the endogenity of institution, the paper selects instrumental variable method to make a regression analysis on Formula 1. The enrollment ratio of secondary school by [31] is selected as an instrumental variable. The calculating data of this, the number of secondary school's enrollment and the number of graduates from primary school, are derived from the Statistical Yearbook for China's Regional Economy.

Table 1 shows the descriptive statistics results of all variables. It shows that there are differences among total factor productivity, marketization, relationship between government and markets, and legal environment in China's 30 provinces, municipalities and autonomous regions.

Table 1. Descriptive statistics of variables.

\begin{tabular}{cccccc}
\hline Variable & Observation & Mean & $\begin{array}{c}\text { Standard } \\
\text { Deviation }\end{array}$ & Minimum & Maximum \\
\hline Lnrgdp & 330 & 8.2507 & 0.9819 & 5.425 & 10.466 \\
Lnk & 330 & 9.1675 & 0.8790 & 6.845 & 11.042 \\
Lnh & 330 & 9.5397 & 0.8315 & 7.283 & 10.874 \\
TFP & 330 & 30.2582 & 9.2769 & 12.8356 & 57.06 \\
Ratio & 330 & 1.3163 & 0.3193 & 0 & 3.979 \\
Market & 330 & 6.0914 & 2.1056 & 1.72 & 11.8 \\
\hline
\end{tabular}


Table 1. Cont.

\begin{tabular}{cccccc}
\hline Variable & Observation & Mean & $\begin{array}{c}\text { Standard } \\
\text { Deviation }\end{array}$ & Minimum & Maximum \\
\hline RGM & 330 & 7.303 & 1.6598 & 2.75 & 10.65 \\
RGM1 & 330 & 7.1814 & 2.7178 & -1.41 & 13.45 \\
RGM2 & 330 & 8.7353 & 2.0299 & 0 & 10.33 \\
RGM3 & 330 & 4.4992 & 2.6944 & -2.17 & 12.67 \\
RGM4 & 330 & 10.8152 & 4.2403 & 0 & 16.46 \\
RGM5 & 330 & 5.2219 & 2.6344 & -1.56 & 10.56 \\
Law & 330 & 5.0838 & 3.1208 & 1.15 & 19.89 \\
Law1 & 330 & 3.7349 & 2.4910 & -0.05 & 10.94 \\
Law2 & 330 & 3.9316 & 1.9896 & -0.46 & 10 \\
Law3 & 330 & 4.978 & 8.3751 & -0.24 & 53.51 \\
Law4 & 330 & 7.6711 & 2.3762 & 0 & 11.17 \\
\hline
\end{tabular}

Note: Lnrgdp is natural logarithm of real GDP; Lnk is natural logarithm of physical capital stock; Lnh is natural logarithm of human capital stock; TFP is total factor productivity; Ratio is enrollment ratio of secondary school; Market is Marketization; RGM is relationship between government and markets; RGM1 is proportion of economic resources allocated through markets; RGM2 is tax and charge burden on farmers; RGM3 is government's excessive administrative intervention in enterprises; RGM4 is enterprises' nontax burden; RGM5 is excessive size of government; Law is development of market intermediaries and the legal environment; Law1 is development of market intermediaries; Law2 is protection of producers' lawful rights and interests; Law3 is protection of intellectual property rights; and Law4 is protection of consumers' interests.

\subsection{Research Method}

As for the evaluation and design of panel data model with instrumental variables, this paper proceeds as follows: first, F Test is used to select fixed effect model with instrumental variables or regression model with instrumental variables; if the fixed effect model with instrumental variables is selected, then a fixed effect model with instrumental variables or a random effect model with instrumental variables shall be selected according to the results of Hausman Test; if the selection is still the fixed effect model with instrumental variables, the test is then finished; if the random effect model with instrumental variables is selected, LM Test on the selection between random effect model with instrumental variables and regression model with instrumental variables should be done as a complementary test.

\section{Empirical Results and Discussion}

\subsection{Regression Results of Institution and Sustainable Economic Development by Inter-Provincial} Panel Data

It is shown in Tables 2 and 3 that the results of panel regression on government governance, legal environment and economic development by inter-provincial panel data. It is indicated in Table 2 that physical capital stock, human capital stock and total factor productivity have significant positive effects on sustainable economic development, and they have passed a $1 \%$ significance test. After the institution variable is added, which means the indexes of marketization, relationship between 
government and markets, development of market intermediaries and the legal environment are added into the model, physical capital stock, human capital stock and total factor productivity still have significant positive impact on sustainable economic development. In other words, physical capital stock, human capital stock and total factor productivity are the main factors in China's sustainable economic development. Meanwhile, we find that each index of the institutional variables shows a significant positive impact on sustainable economic development, namely, it plays a significant role in promoting sustainable economic development, which is consistent with the conclusions of existing research literatures [32-34].

Table 2. Regression results of institution and sustainable economic development by inter-provincial panel data.

\begin{tabular}{|c|c|c|c|c|}
\hline Variables & Model 1 & Model 2 & Model 3 & Model 4 \\
\hline Constant & $\begin{array}{c}-2.1289 * * * \\
(-6.09)\end{array}$ & $\begin{array}{l}-0.1997 \\
(-0.26)\end{array}$ & $\begin{array}{c}-3.0717 * * * \\
(-4.34)\end{array}$ & $\begin{array}{c}-6.3886 * * * \\
(-3.56)\end{array}$ \\
\hline Market & & $\begin{array}{c}0.1137 * * * \\
(3.57) \\
\end{array}$ & & \\
\hline RGM & & & $\begin{array}{c}0.1152 * * * \\
(2.98) \\
\end{array}$ & \\
\hline Law & & & & $\begin{array}{c}0.0762 * * * \\
(2.60)\end{array}$ \\
\hline Lnk & $\begin{array}{c}0.7086^{* * *} \\
(52.11)\end{array}$ & $\begin{array}{c}0.6174 * * * \\
(18.81)\end{array}$ & $\begin{array}{c}0.6539 * * * \\
(21.28)\end{array}$ & $\begin{array}{c}0.7190 * * * \\
(25.22)\end{array}$ \\
\hline Lnh & $\begin{array}{c}0.3210 * * * \\
(8.27)\end{array}$ & $\begin{array}{c}0.1867 * * * \\
(2.68)\end{array}$ & $\begin{array}{c}0.4365 * * * \\
(5.43)\end{array}$ & $\begin{array}{c}0.7543 * * * \\
(4.07)\end{array}$ \\
\hline TFP & $\begin{array}{c}0.0271 * * * \\
(33.35)\end{array}$ & $\begin{array}{c}0.0104 * * \\
(2.16)\end{array}$ & $\begin{array}{c}0.0106^{*} \\
(1.85)\end{array}$ & $\begin{array}{c}0.0409 * * * \\
(7.33)\end{array}$ \\
\hline $\mathrm{R}^{2}$ & 0.9943 & 0.9700 & 0.9787 & 0.9619 \\
\hline Wald $\chi^{2}$ & $11115.61 * * *$ & $5.73 \mathrm{e}+06^{* * *}$ & $\begin{array}{c}4.00 \mathrm{e}+06 \\
* * *\end{array}$ & $3.05 \mathrm{e}+06 * * *$ \\
\hline F test & $12.91 * * *$ & $5.97 * * *$ & $4.05 * * *$ & $2.83 * * *$ \\
\hline $\begin{array}{c}\text { Hausman } \\
\text { test }\end{array}$ & $57.92 * * *$ & $72.73 * * *$ & $32.36 * * *$ & $109.50 * * *$ \\
\hline
\end{tabular}

Note: the method is instrumental variables regression for panel data; the values in brackets represent the statistic $\mathrm{Z} ; *$ indicates significance at the $10 \%$ level; ** indicates significance at the $5 \%$ level; *** indicates significance at the $1 \%$ level. 
Table 3. Regression results of government governance, legal environment and sustainable economic development by inter-provincial panel data.

\begin{tabular}{|c|c|c|c|c|c|c|c|c|c|}
\hline Variables & Model 1 & Model 2 & Model 3 & Model 4 & Model 5 & Model 6 & Model 7 & Model 8 & Model 9 \\
\hline Constant & $\begin{array}{c}-2.6371 * * * \\
(-15.68)\end{array}$ & $\begin{array}{c}-3.0779 * * * \\
(-6.31)\end{array}$ & $\begin{array}{c}-2.5972 * * * \\
(-6.53)\end{array}$ & $\begin{array}{c}-2.1515 * * * \\
(-33.88)\end{array}$ & $\begin{array}{c}-3.9878 * \\
(-1.81)\end{array}$ & $\begin{array}{c}-2.0594 * * * \\
(-38.91)\end{array}$ & $\begin{array}{c}-0.1606 \\
(-0.14)\end{array}$ & $\begin{array}{c}-4.1787 * * * \\
(-7.38)\end{array}$ & $\begin{array}{c}-1.9341 * * * \\
(-14.34)\end{array}$ \\
\hline RGM1 & $\begin{array}{c}-0.0384 * * * \\
(-3.68)\end{array}$ & & & & & & & & \\
\hline RGM2 & & $\begin{array}{c}0.0400 * * * \\
(4.33)\end{array}$ & & & & & & & \\
\hline RGM3 & & & $\begin{array}{c}-0.0911 \\
(-1.41) \\
\end{array}$ & & & & & & \\
\hline RGM4 & & & & $\begin{array}{c}0.0200 * * * \\
(5.13)\end{array}$ & & & & & \\
\hline RGM5 & & & & & $\begin{array}{c}-0.1965 \\
(-0.88) \\
\end{array}$ & & & & \\
\hline Law1 & & & & & & $\begin{array}{c}0.0436 * * * \\
(3.37)\end{array}$ & & & \\
\hline Law2 & & & & & & & $\begin{array}{c}0.0624 \text { ** } \\
(2.43)\end{array}$ & & \\
\hline Law3 & & & & & & & & $\begin{array}{c}-0.0109 * * * \\
(-4.92)\end{array}$ & \\
\hline Law4 & & & & & & & & & $\begin{array}{c}0.0840 * * * \\
(2.75) \\
\end{array}$ \\
\hline $\operatorname{lnk}$ & $\begin{array}{c}0.6516 * * * \\
(30.55)\end{array}$ & $\begin{array}{c}0.6135 * * * \\
(22.13)\end{array}$ & $\begin{array}{c}0.7954 * * * \\
(5.45)\end{array}$ & $\begin{array}{c}0.6601 * * * \\
(48.49)\end{array}$ & $\begin{array}{c}0.6679 * * * \\
(6.62)\end{array}$ & $\begin{array}{c}0.5095 * * * \\
(16.38)\end{array}$ & $\begin{array}{c}0.6888 * * * \\
(22.07)\end{array}$ & $\begin{array}{c}0.6434 * * * \\
(32.27)\end{array}$ & $\begin{array}{c}0.5283 * * * \\
(12.02)\end{array}$ \\
\hline $\operatorname{lnh}$ & $\begin{array}{c}0.4525 \text { *** } \\
(22.57) \\
\end{array}$ & $\begin{array}{c}0.4972 * * * \\
(7.87) \\
\end{array}$ & $\begin{array}{c}0.3115 * * * \\
(3.86) \\
\end{array}$ & $\begin{array}{c}0.3749 * * * \\
(31.58) \\
\end{array}$ & $\begin{array}{c}0.7071 * * \\
(2.06) \\
\end{array}$ & $\begin{array}{c}0.4979 * * * \\
(18.57) \\
\end{array}$ & $\begin{array}{c}0.1003 \\
(0.80) \\
\end{array}$ & $\begin{array}{c}0.5861 * * * \\
(8.54) \\
\end{array}$ & $\begin{array}{c}0.4412 * * * \\
(16.22) \\
\end{array}$ \\
\hline TFP & $\begin{array}{c}0.0288 * * * \\
(22.10)\end{array}$ & $\begin{array}{c}0.0201 * * * \\
(10.62)\end{array}$ & $\begin{array}{c}0.0328 * * * \\
(10.24)\end{array}$ & $\begin{array}{c}0.0183 * * * \\
(8.93) \\
\end{array}$ & $\begin{array}{c}0.0130 \\
(0.75) \\
\end{array}$ & $\begin{array}{c}0.0239 * * * \\
(13.87)\end{array}$ & $\begin{array}{c}0.0295 * * * \\
(14.34) \\
\end{array}$ & $\begin{array}{c}0.0328 * * * \\
(22.41) \\
\end{array}$ & $\begin{array}{c}0.0161 * * * \\
(3.47) \\
\end{array}$ \\
\hline $\mathrm{R}^{2}$ & 0.9904 & 0.9900 & 0.9608 & 0.9948 & 0.8115 & 0.9923 & 0.9337 & 0.9888 & 0.9822 \\
\hline Wald $\chi^{2}(\mathrm{~F})^{2}$ & $6545.18 * * *$ & $8.46 \mathrm{e}+06^{* * *}$ & $1534.57 * * *$ & $46143.22 * * *$ & $683.65 * * *$ & $11280.62 * * *$ & $2.67 \mathrm{e}+06 * * *$ & $1.09 \mathrm{e}+07^{* * *}$ & $14051.36^{* * *}$ \\
\hline $\mathrm{F}$ test & 0.02 & $8.14 * * *$ & 0.05 & $4.06 * * *$ & 0.01 & $2.64 * * *$ & $2.68 * * *$ & $9.75 * * *$ & $3.96 * * *$ \\
\hline Hausman test & 0.12 & $9.78 * *$ & 0.41 & 2.45 & 2.58 & 2.03 & $22.93 * * *$ & $118.20 * * *$ & 0.04 \\
\hline LM test & $208.54 * * *$ & & $238.03 * * *$ & $323.52 * * *$ & $224.82 * * *$ & $220.58 * * *$ & & & $349.75 * * *$ \\
\hline
\end{tabular}

Note: 1 . The method is instrumental variables regression for panel data; the values in brackets represent the statistic $\mathrm{Z}$; $*$ indicates significance at the $10 \%$ level;

$* *$ indicates significance at the $5 \%$ level; *** indicates significance at the $1 \%$ level; 2 . When LM test is implemented in model, it is $\mathrm{F}$ test value, or it is Wald $\chi^{2}$ value. 
Then, which institutional factors have effects on sustainable economic development? It is shown in Table 3 that the results of panel regression on each index of relationship between government and markets, development of market intermediaries and the legal environment and sustainable economic development of inter-provincial panel data. Physical capital stock is still significant in all models, while human capital stock and total factor productivity is not significant in only one model; meanwhile, the results of the relationship between government and market indexes are surprising: the proportion of economic resources allocated through market shows a significantly negative impact on sustainable economic development, namely, the more economic resources are allocated through market, the less economic development would be seen, which totally run counter to the theory of economic development. Considering the symbol of the index of reducing government's excessive administrative intervention in enterprises, it can be seen that the market economy has been implemented by the Chinese government since 1994, but China's enterprises are still difficult to adapt to the operating environment of market economy because they are used to receiving economic resources allocated through the government. The index of reducing the excessive size of government shows a negative impact on sustainable economic development, but not a significant one. It indicates that the government scale cannot be reduced blindly, and the key is the scope of the government's jurisdiction; the efficiency of the civil servants rather than the numbers of them. The two indexes of reducing the tax and charge burden on farmers and reducing the enterprises' nontax burden show a significantly positive impact on sustainable economic development, which confirms the promotion effect that the more government's reducing the tax and charge burden on farmers and enterprises' nontax burden, the better sustainable regional economy would develop. Models 6-9 show that the impact of legal environment's indexes on sustainable economic development passes a $1 \%$ significance test. Among which, the development of market intermediaries, the protection of the producers' lawful rights and interests and the protection of consumers' interests, and their sign is positive, which means the better these factors are, the faster the sustainable economic development is. However, the relationship between protection of intellectual property rights and sustainable economic development is in a negative correlation, which means the better protection of intellectual property rights is, the slower the sustainable economic development is. It may result from a lower level of economic development in China. An empirical study of Thompson and Rushing (1996, 1999) find that in developed countries, patent protection can effectively promote the total factor productivity; while in developing countries, the implementation of minimum standards for the patent protection would not promote economic development, unless the economic development of the country has reached a certain level $[35,36]$.

\subsection{Regression Results of Institution and Sustainable Economic Development by Eastern and Western} Panel Data

For a long time in history, Midwestern China, especially Western China is fairly secluded, where the dominant institution shows characteristics of Chinese traditional feudal natural economy: physiocracy, value just above material gains, individual's subjecting to the government and authority, ignoring the rule of law. Therefore, compared with Eastern China, Midwestern China has a less developed commodity economy and lacks the awareness of commerce. Meanwhile, China's reform is a 
gradual process of institutional transformation. According to the reform plan of the central government, the reform shall be implemented in Eastern Coastal Regions first as a pilot reform, and then is introduced to the Midwestern China. These regional differences in the order of the formal and informal institutional reforms together determine the differences in China's regional sustainable economic development. Do the above-mentioned conclusions still have strong robustness after taking these factors into account? To this end, this paper respectively surveys the impact of each institutional index in the eastern and western regions on regional sustainable economic development.

Table 4 shows the regression results of government governance, legal environment and sustainable economic development by the Eastern and Western panel data. It is indicated in Table 4 that those indexes of marketization, relationship between government and markets, development of market intermediaries and the legal environment in Eastern China are consistent with the regression results in inter-provincial panel data, which shows a significant positive correlation. It confirms the view that a better legal system leads to better economic performance. While those indexes of marketization, relationship between government and markets and legal environment are still consistent with the regression results in Eastern China, they are not significant in Western China. The significant impact of marketization, relationship between government and markets and legal environment on sustainable economic development has not yet been shown completely. Therefore, further improvement of the government governance and legal system in Western China plays an important and critical role in sustainable economic development. The conclusion is consistent with the results of [37]'s cross-country data, whereby they found that government governance does not bring significant economic growth when countries are in a lower income stage, but in higher income stages, there is a strong correlation between government governance and economic output.

Table 5 shows that, in Eastern China, the indexes of relationship between government and markets and sustainable economic development are still the same with the sign of variables in inter-provincial panel data, but the levels of significance are different. The index of proportion of economic resources allocated through market and reducing enterprises' nontax burden have passed the $10 \%$ significance test; the index of reducing tax and charge burden on farmers has passed the $1 \%$ significance test. The index of reducing government's excessive administrative intervention in enterprises and reducing excessive size of government has not passed $10 \%$ the significance test, which indicates the effect of government governance still needs to be tested, and the significant effect is still not shown completely. In Western China, the impact of the indexes of relationship between government and markets on regional sustainable economic development show a great difference with that in Eastern China. All the indexes show a positive correlation but do not pass the $10 \%$ significance test, which indicates that the impact of the indexes of relationship between government and markets on regional sustainable economic development is limited in Western China. 
Table 4. Regression results of institution and sustainable economic development by eastern and western panel data.

\begin{tabular}{|c|c|c|c|c|c|c|c|c|}
\hline \multirow{2}{*}{ Variables } & \multicolumn{4}{|c|}{ Eastern } & \multicolumn{4}{|c|}{ Western } \\
\hline & Model 1 & Model 2 & Model 3 & Model 4 & Model 5 & Model 6 & Model 7 & Model 8 \\
\hline Constant & $\begin{array}{c}-1.6624 * * * \\
(-3.99) \\
\end{array}$ & $\begin{array}{c}-0.1529 \\
(-0.22) \\
\end{array}$ & $\begin{array}{c}-2.1040 \text { *** } \\
(-22.55) \\
\end{array}$ & $\begin{array}{c}-2.2214 * * * \\
(-5.14)\end{array}$ & $\begin{array}{c}-3.8140 \text { *** } \\
(-7.66)\end{array}$ & $\begin{array}{c}-3.3043 * * * \\
(-5.61) \\
\end{array}$ & $\begin{array}{c}-3.5906 \text { *** } \\
(-6.65) \\
\end{array}$ & $\begin{array}{l}-3.1903 \\
(-1.81) \\
\end{array}$ \\
\hline Market & & $\begin{array}{c}0.0700 * * * \\
(3.47) \\
\end{array}$ & & & & $\begin{array}{c}0.0342 \\
(1.31) \\
\end{array}$ & & \\
\hline RGM & & & $\begin{array}{c}0.0784 * \\
(1.81)\end{array}$ & & & & $\begin{array}{l}0.0317 \\
(1.15)\end{array}$ & \\
\hline Law & & & & $\begin{array}{c}0.0067 * * * \\
(3.34)\end{array}$ & & & & $\begin{array}{c}0.1196 \\
(0.48)\end{array}$ \\
\hline Lnk & $\begin{array}{c}0.6386 * * * \\
(26.94)\end{array}$ & $\begin{array}{c}0.5943 * * * \\
(17.85)\end{array}$ & $\begin{array}{c}0.5508 * * * \\
(23.74)\end{array}$ & $\begin{array}{c}0.6562 * * * \\
(28.21)\end{array}$ & $\begin{array}{c}0.5393 * * * \\
(20.22)\end{array}$ & $\begin{array}{c}0.5237 * * * \\
(19.74)\end{array}$ & $\begin{array}{c}0.5791 * * * \\
(13.21)\end{array}$ & $\begin{array}{c}0.3540 \\
(0.91)\end{array}$ \\
\hline Lnh & $\begin{array}{c}0.3404 * * * \\
(7.14)\end{array}$ & $\begin{array}{c}0.2095 * * * \\
(2.89)\end{array}$ & $\begin{array}{c}0.4352 * * * \\
(18.16)\end{array}$ & $\begin{array}{c}0.3821^{* * *} \\
(8.09)\end{array}$ & $\begin{array}{c}0.6347^{* * *} \\
(10.63)\end{array}$ & $\begin{array}{c}0.5891 * * * \\
(9.29)\end{array}$ & $\begin{array}{c}0.5681 * * * \\
(6.79)\end{array}$ & $\begin{array}{c}0.7261 * * * \\
(3.06)\end{array}$ \\
\hline TFP & $\begin{array}{c}0.0264 * * * \\
(27.69) \\
\end{array}$ & $\begin{array}{c}0.0165 * * * \\
(5.32)\end{array}$ & $\begin{array}{c}0.0190 * * * \\
(4.85)\end{array}$ & $\begin{array}{c}0.0274 * * * \\
(28.63) \\
\end{array}$ & $\begin{array}{c}0.0387^{* * *} \\
(21.02) \\
\end{array}$ & $\begin{array}{c}0.0337 \text { *** } \\
(8.21) \\
\end{array}$ & $\begin{array}{c}0.0322 * * * \\
(5.44) \\
\end{array}$ & $\begin{array}{l}0.0269 \\
(1.09) \\
\end{array}$ \\
\hline $\mathrm{R}^{2}$ & 0.9940 & 0.9767 & 0.9946 & 0.9964 & 0.9897 & 0.9913 & 0.9890 & 0.9803 \\
\hline Wald $\chi^{2}(F)^{2}$ & $5649.85 * * *$ & $4.39 \mathrm{e}+06 * * *$ & $4056.95 * * *$ & $4642.02 * * *$ & $6971.24 * * *$ & $8.20 \mathrm{e}+06 * * *$ & $6.32 \mathrm{e}+06 * * *$ & $1.12 \mathrm{e}+06 * * *$ \\
\hline F test & $12.07 * * *$ & $5.48 * * *$ & 1.47 & 1.51 & $14.29 * * *$ & $15.12 * * *$ & $9.79 * * *$ & $2.27 * *$ \\
\hline Hausman test & $6.31 *$ & $84.23 * * *$ & 1.17 & 1.15 & $13.01 * * *$ & 3.07 & 3.52 & 2.07 \\
\hline LM test & & & $77.46 * * *$ & $109.79 * * *$ & & $130.88 * * *$ & $83.52 * * *$ & $105.18 * * *$ \\
\hline
\end{tabular}

Note: 1 . The method is instrumental variables regression for panel data, the values in brackets represent the statistic $\mathrm{Z}$, * indicates significance at the $10 \%$ level, ** indicates significance at the $5 \%$ level, *** indicates significance at the $1 \%$ level; 2 . When LM test is implemented in model, it is $\mathrm{F}$ test value, or it is Wald $\chi^{2}$ value. 
Table 5. Regression results of government governance and sustainable economic development by eastern and western panel data.

\begin{tabular}{|c|c|c|c|c|c|c|c|c|c|c|}
\hline \multirow{2}{*}{ Variables } & \multicolumn{5}{|c|}{ Eastern } & \multicolumn{5}{|c|}{ Western } \\
\hline & Model 1 & Model 2 & Model 3 & Model 4 & Model 5 & Model 6 & Model 7 & Model 8 & Model 9 & Model 10 \\
\hline Constant & $\begin{array}{c}-1.4211 \\
(-1.26) \\
\end{array}$ & $\begin{array}{c}-2.0214 * * * \\
(-5.05)\end{array}$ & $\begin{array}{c}-2.2136 * * * \\
(-10.98) \\
\end{array}$ & $\begin{array}{c}-0.6984 \\
(-0.65) \\
\end{array}$ & $\begin{array}{c}-2.2359 * * * \\
(-7.32) \\
\end{array}$ & $\begin{array}{c}-3.8617 * * * \\
(-6.32)\end{array}$ & $\begin{array}{c}-3.7432 * * * \\
(-5.30) \\
\end{array}$ & $\begin{array}{c}-3.5341 * * * \\
(-5.65) \\
\end{array}$ & $\begin{array}{c}-1.4430 \\
(-0.46) \\
\end{array}$ & $\begin{array}{c}-1.3682 * * * \\
(-2.81)\end{array}$ \\
\hline RGM1 & $\begin{array}{c}-0.0869 * \\
(-1.67)\end{array}$ & & & & & $\begin{array}{l}0.0238 \\
(0.95)\end{array}$ & & & & \\
\hline RGM2 & & $\begin{array}{c}0.0337 * * * \\
(4.77)\end{array}$ & & & & & $\begin{array}{l}0.0333 \\
(0.83) \\
\end{array}$ & & & \\
\hline RGM3 & & & $\begin{array}{l}-0.0444 \\
(-1.15)\end{array}$ & & & & & $\begin{array}{r}0.0149 \\
(1.03)\end{array}$ & & \\
\hline RGM4 & & & & $\begin{array}{c}0.0460 * \\
(1.97)\end{array}$ & & & & & $\begin{array}{l}0.0333 \\
(0.78) \\
\end{array}$ & \\
\hline RGM5 & & & & & $\begin{array}{l}-0.0953 \\
(-0.84)\end{array}$ & & & & & $\begin{array}{l}0.0628 \\
(1.60) \\
\end{array}$ \\
\hline Lnk & $\begin{array}{c}0.4020 * * * \\
(2.59)\end{array}$ & $\begin{array}{c}0.5793 * * * \\
(22.64) \\
\end{array}$ & $\begin{array}{c}0.6311 * * * \\
(8.95) \\
\end{array}$ & $\begin{array}{c}0.5247 * * * \\
(6.62) \\
\end{array}$ & $\begin{array}{c}0.7040 * * * \\
(4.44) \\
\end{array}$ & $\begin{array}{c}0.5794 * * * \\
(10.89) \\
\end{array}$ & $\begin{array}{c}0.6242 * * * \\
(5.72) \\
\end{array}$ & $\begin{array}{c}0.5154 * * * \\
(13.53) \\
\end{array}$ & $\begin{array}{c}0.6150 * * * \\
(5.90) \\
\end{array}$ & $\begin{array}{c}0.7330 * * * \\
(7.79) \\
\end{array}$ \\
\hline Lnh & $\begin{array}{c}0.6336 * * * \\
(2.92)\end{array}$ & $\begin{array}{c}0.4180 * * * \\
(8.74) \\
\end{array}$ & $\begin{array}{c}0.4174 * * * \\
(9.18) \\
\end{array}$ & $\begin{array}{c}0.3765 * * * \\
(3.41) \\
\end{array}$ & $\begin{array}{c}0.4229 * * * \\
(10.58) \\
\end{array}$ & $\begin{array}{c}0.5950 * * * \\
(7.07) \\
\end{array}$ & $\begin{array}{c}0.5587 * * * \\
(4.49) \\
\end{array}$ & $\begin{array}{c}0.6135 * * * \\
(8.68) \\
\end{array}$ & $\begin{array}{l}0.3249 \\
(0.80) \\
\end{array}$ & $\begin{array}{c}0.1423 * * * \\
(0.86)\end{array}$ \\
\hline TFP & $\begin{array}{c}0.0266 * * * \\
(10.35) \\
\end{array}$ & $\begin{array}{c}0.0230 * * * \\
(19.99)\end{array}$ & $\begin{array}{c}0.0310 * * * \\
(7.38) \\
\end{array}$ & $\begin{array}{c}0.0068 \\
(0.67) \\
\end{array}$ & $\begin{array}{c}0.0179 * \\
(1.93) \\
\end{array}$ & $\begin{array}{c}0.0368 * * * \\
(12.45) \\
\end{array}$ & $\begin{array}{l}0.0229 \\
(1.19) \\
\end{array}$ & $\begin{array}{c}0.0415 * * * \\
(12.02) \\
\end{array}$ & $\begin{array}{r}0.0166 \\
(0.59) \\
\end{array}$ & $\begin{array}{c}0.0437 * * * \\
(8.02)\end{array}$ \\
\hline $\mathrm{R}^{2}$ & 0.9739 & 0.9970 & 0.9878 & 0.9782 & 0.9723 & 0.9878 & 0.9834 & 0.9917 & 0.9899 & 0.9797 \\
\hline Wald $\chi^{2}(\mathrm{~F})^{2}$ & $1.02 \mathrm{e}+06 * * *$ & $8.31 \mathrm{e}+06 * * *$ & $1583.16 * * *$ & $1.41 \mathrm{e}+06 * * *$ & $1255.73 * * *$ & $4.33 \mathrm{e}+06 * * *$ & $3.27 \mathrm{e}+06 * * *$ & $5.05 \mathrm{e}+06^{* * *}$ & $2.93 \mathrm{e}+06 * * *$ & $3142.76 * * *$ \\
\hline $\mathrm{F}$ test & $1.85 *$ & $12.19 * * *$ & 0.03 & $2.37 * *$ & 0.49 & $8.50 * * *$ & $5.09 * * *$ & $10.65 * * *$ & $4.69 * * *$ & 0.39 \\
\hline Hausman test & 4.01 & $20.88 * * *$ & 0.05 & 4.56 & 0.78 & 6.98 & 4.14 & 3.16 & 0.47 & 1.49 \\
\hline LM test & $72.97 * * *$ & & $99.01 * * *$ & $119.5 * * *$ & $87.23 * * *$ & $94.62 * * *$ & $76.23 * * *$ & $90.48 * * *$ & $137.04 * * *$ & $82.11 * * *$ \\
\hline
\end{tabular}

Note: 1 . The method is instrumental variables regression for panel data; the values in brackets represent the statistic Z; * indicates significance at the $10 \%$ level;

** indicates significance at the $5 \%$ level; *** indicates significance at the $1 \%$ level; 2 . When LM test is implemented in model, it is $\mathrm{F}$ test value, or it is Wald $\chi^{2}$ value. 
Table 6. Regression results of legal environment and sustainable economic development by eastern and western panel data.

\begin{tabular}{|c|c|c|c|c|c|c|c|c|}
\hline \multirow{2}{*}{ Variables } & \multicolumn{4}{|c|}{ Eastern } & \multicolumn{4}{|c|}{ Western } \\
\hline & Model 1 & Model 2 & Model 3 & Model 4 & Model 5 & Model 6 & Model 7 & Model 8 \\
\hline Constant & $\begin{array}{c}-1.1762 \\
(-1.82) \\
\end{array}$ & $\begin{array}{c}-1.5013 * * \\
(-2.57) \\
\end{array}$ & $\begin{array}{c}-3.7150 * * * \\
(-5.06) \\
\end{array}$ & $\begin{array}{c}-0.7955 * * \\
(-2.10) \\
\end{array}$ & $\begin{array}{c}-3.8166 * * * \\
(-7.95) \\
\end{array}$ & $\begin{array}{c}-2.1478 * * * \\
(-46.17) \\
\end{array}$ & $\begin{array}{c}-2.2056 * * * \\
(-16.61) \\
\end{array}$ & $\begin{array}{c}-2.1478 * * * \\
(-45.76) \\
\end{array}$ \\
\hline Law1 & $\begin{array}{c}0.0389 * * * \\
(3.00) \\
\end{array}$ & & & & $\begin{array}{r}0.0275 \\
(1.21) \\
\end{array}$ & & & \\
\hline Law2 & & $\begin{array}{c}0.0331 * * * \\
(3.22) \\
\end{array}$ & & & & $\begin{array}{l}-0.0011 \\
(-0.38) \\
\end{array}$ & & \\
\hline Law3 & & & $\begin{array}{c}-0.0070 * * * \\
(-3.79) \\
\end{array}$ & & & & $\begin{array}{l}0.0033 \\
(1.19) \\
\end{array}$ & \\
\hline Law4 & & & & $\begin{array}{c}0.0417 * * * \\
(5.47)\end{array}$ & & & & $\begin{array}{c}0.0002 \\
(0.10) \\
\end{array}$ \\
\hline Lnk & $\begin{array}{c}0.4384 * * * \\
(5.79) \\
\end{array}$ & $\begin{array}{c}0.6755 * * * \\
(19.29)\end{array}$ & $\begin{array}{c}0.6609 * * * \\
(22.98)\end{array}$ & $\begin{array}{c}0.4615 * * * \\
(12.20) \\
\end{array}$ & $\begin{array}{c}0.4785 * * * \\
(8.46) \\
\end{array}$ & $\begin{array}{c}0.5946 * * * \\
(37.66) \\
\end{array}$ & $\begin{array}{c}0.5530 * * * \\
(21.85) \\
\end{array}$ & $\begin{array}{c}0.5946 * * * \\
(37.55) \\
\end{array}$ \\
\hline Lnh & $\begin{array}{c}0.4818 * * * \\
(5.62)\end{array}$ & $\begin{array}{c}0.2738 * * * \\
(3.93)\end{array}$ & $\begin{array}{c}0.5284 * * * \\
(7.02)\end{array}$ & $\begin{array}{c}0.3930 * * * \\
(9.72)\end{array}$ & $\begin{array}{c}0.6942 * * * \\
(9.16)\end{array}$ & $\begin{array}{c}0.4085 * * * \\
(35.33)\end{array}$ & $\begin{array}{c}0.4434 * * * \\
(20.37) \\
\end{array}$ & $\begin{array}{c}0.4085 * * * \\
(35.32)\end{array}$ \\
\hline TFP & $\begin{array}{c}0.0238 * * * \\
(14.20)\end{array}$ & $\begin{array}{c}0.0249 * * * \\
(17.58)\end{array}$ & $\begin{array}{c}0.0291 * * * \\
(21.82)\end{array}$ & $\begin{array}{c}0.0259 * * * \\
(32.66)\end{array}$ & $\begin{array}{c}0.0347 * * * \\
(9.25)\end{array}$ & $\begin{array}{l}0.0361 \\
(30.47) \\
\end{array}$ & $\begin{array}{c}0.0397 * * * \\
(24.95)\end{array}$ & $\begin{array}{c}0.0361 * * * \\
(30.50)\end{array}$ \\
\hline $\mathrm{R}^{2}$ & 0.9868 & 0.9828 & 0.9931 & 0.9892 & 0.9877 & 0.9972 & 0.9971 & 0.9972 \\
\hline Wald $\chi^{2}(\mathrm{~F})^{2}$ & $3.28 \mathrm{e}+06 * * *$ & $\begin{array}{c}3.79 \mathrm{e}+06 \\
* * *\end{array}$ & $5.24 \mathrm{e}+06 * * *$ & $1.09 \mathrm{e}+07 * * *$ & $6.96 \mathrm{e}+06 * * *$ & $14935.01 * * *$ & $22920.58 * * *$ & $12601.50 * * *$ \\
\hline F test & $5.75 * * *$ & $7.09 * * *$ & $9.94 * * *$ & $14.81 * * *$ & $10.23 * * *$ & 0.93 & 0.81 & 0.01 \\
\hline Hausman test & $51.94 * * *$ & 0.04 & $55.82 * * *$ & $8.63 *$ & $10.82 * *$ & 0.57 & $13.93 * * *$ & 0.43 \\
\hline LM test & & $93.93 * * *$ & & & & $101.19 * * *$ & $98.23 * * *$ & $103.86 * * *$ \\
\hline
\end{tabular}

Note: 1. The method is instrumental variables regression for panel data, the values in brackets represent the statistic $\mathrm{Z}$, $*$ indicates significance at the $10 \%$ level,

$* *$ indicates significance at the $5 \%$ level, *** indicates significance at the $1 \%$ level; 2 . When LM test is implemented in model, it is $\mathrm{F}$ test value, or it is Wald $\chi^{2}$ value. 
Table 6 shows the impact of development of market intermediaries and legal environment's indexes on sustainable economic development in Eastern China. These results are the same as the regression results of China's inter-provincial panel data. However, while the protection of intellectual property rights shows a significantly negative impact on regional sustainable economic development, other indexes show a significantly positive impact. In Western China, while the index sign of the protection of producers' lawful rights and interests is negative, the sign of development of market intermediaries, protection of intellectual property rights and protection of consumers' interests are positive but not significant. This further illustrates that the level of economic sustainable development is determined by the different legal environments in Eastern and Western China. These conclusions confirm [38]'s results that the development of law system (a formal contract subject) will gradually become more and more important as economic development reaches a higher stage.

\section{Conclusions}

On the basis of the indexes of marketization, relationship between government and markets, development of market intermediaries and the legal environment in each region by Fan et al. [23], and by controlling physical capital, human capital and productivity, this paper uses inter-provincial panel data from 1999-2009 to make a comprehensive survey on the relationship between institutional indexes, like government governance and legal environment, and sustainable economic development. Some interesting results are found as follows:

First, physical capital stock, human capital stock and total factor productivity have a significant promoting effect on sustainable economic development; in inter-provincial panel data and Eastern China's panel data, the indexes of marketization, relationship between government and markets, development of market intermediaries and the legal environment have a significant promoting effect on sustainable economic development; while their promoting effect in Western China's panel data is not significant.

Second, the impact of indexes of relationship between government and markets on sustainable economic development is significantly different among inter-provincial panel data and Eastern China's panel data and Western China's panel data. In inter-provincial panel data and Eastern China's panel data, the proportion of economic resources allocated through market and sustainable economic development shows a significantly negative correlation; reducing tax and charge burden on farmers and reducing enterprises' nontax burden show a significantly positive impact on sustainable economic development; reducing government's excessive administrative intervention in enterprises and reducing excessive size of government show an insignificantly negative impact on sustainable economic development; in Western China's panel data, indexes of relationship between government and markets show an insignificantly negative impact on sustainable economic development.

Third, the impact of indexes of development of market intermediaries and the legal environment on sustainable economic development is significantly different in inter-provincial panel data and Eastern China's panel data and Western China's panel data. In inter-provincial panel data and Eastern China's panel data, except protection of intellectual property rights, other indexes of development of market intermediaries and the legal environment show a significant positive impact on sustainable economic development; while in Western China's panel data, except protection of producers' lawful rights and 
interests shows an insignificant negative impact on sustainable economic development, other indexes show an insignificant positive correlation.

\section{Acknowledgments}

We thank two anonymous reviewers for many constructive comments that helped improve the quality of the paper, and financial support of the MOE (Ministry of Education in China) Project of Humanities and Social Sciences (Project No. 10YJC790122) and Fundamental Research Funds for the Central Universities (Project No. CDJSK100207, CDJKXB13006).

\section{Author Contributions}

Feng Wei performed the data analyses, drafting and revising the manuscript. Yu Kong organized and interpreted data and approved the final version.

\section{Conflicts of Interest}

The authors declare no conflict of interest.

\section{References}

1. Naughton, B. Chinese Institutional Innovation and Privatization from Below. Am. Econ. Rev. 1994, 84, 266-270.

2. Klenow, P.J. Comment on "It's Not Factor Accumulation: Stylized Facts and Growth Models" by William Easterly and Ross Levine. World Bank Econ. Rev. 2001, 15, 221-224.

3. Chen, X.S.; Xu, Y. Factors Affecting China's Regional Gap: An Empirical Study. Soc. Sci. China 2004, 5, 117-129.

4. Hong, X.J. Regional Inequality, Polarization and Mobility in China. Econ. Res. J. 2010, 12, 82-96.

5. Helpman, E. The Mystery of Economic Growth; MIT Press: Boston, MA, USA, 2004.

6. Solow, R.M. A Contribution to the Theory of Economic Growth. Q. J. Econ. 1956, 70, 65-94.

7. Koopmans, T.C. On the Concept of Optimal Economic Growth. Available online: http://cowles.econ.yale.edu/P/cd/d01b/d0163-a.pdf (accessed on 6 September 2013).

8. Romer, P. Increasing Returns and Long-run Growth. J. Polit. Econ. 1986, 98, 71-102.

9. Lucas, R.E. On the Mechanics of Economic Development. J. Mon. Econ. 1988, 22, 3-42.

10. North, D.C. Institution, Institutional Change and Economic Performance; Cambridge University Press: Cambridge, MA, USA, 1990.

11. North, D.C. Economic Performance through Time. Am. Econ. Rev. 1994, 84, 359-368

12. DeLong, J.B.; Shleifer, A. Princes and Merchants: European City Growth before the Industrial Revolution. J. Law Econ. 1993, 36, 671-702

13. Knack, S.; Keefer, P. Institutions and Economic Performance: Cross-Country Tests Using Alternative Measures. Econ. Polit. 1995, 7, 207-227.

14. Acemoglu, D.; Johnson, S. Unbundling Institutions. J. Polit. Econ. 2005, 113, 949-995.

15. Frankel, J.A.; Romer, D. Does Trade Cause Growth? Am. Econ. Rev. 1999, 89, 379-399. 
16. Rodrik, D. Where Did All the Growth Go? External Shocks, Social Conflict, and Growth Collapses. J. Econ. Gro. 1999, 4, 385-412.

17. Barro, R.J. Inequality and Growth in a Panel of Countries. J. Econ. Gro. 2000, 5, 5-32.

18. Mauro, P. Corruption and Growth. Q. J. Econ. 1995, 110, 681-712.

19. Acemoglu, D.; Johnson, S.; Robinson, J.A. Colonial Origins of Comparative Development: An Empirical Investigation. Am. Econ. Rev.2001, 91, 1369-1401.

20. Acemoglu, D.; Johnson, S.; Robinson, J. Institutions as the Fundamental Cause of Long-Run Economic Growth. Handb. Econ. Gro. 2004, 1, 386-414.

21. Wang, X.L.; Fan, G. Analysis on the Regional Disparity in China and the Influential Factors. Econ. Res. J. 2004, 1, 33-44.

22. Xu, Z.Y.; Li, S.T. Analysis on the Trend of Regional Income Disparity in China. Econ. Res. J. 2006, 7, 106-116.

23. Fan, G.; Wang, X.; Zhu, H. NERI Index of Marketization for China's Provinces: 2011 Report; Economic Science Press: Beijing, China, 2011.

24. Butkiewicz, J.L.; Yanikkaya, H. Institutional Quality and Economic Growth: Maintenance of the Rule of Law or Democratic Institutions, or both? Econ. Mod. 2006, 23, 648-661.

25. Cavalcanti, T.V.; Magalhaes, A.M.; Tavares, J.A. Institutions and Economic Development in Brazil. Q. Rev. Econ. Fin. 2008, 48, 412-432.

26. Weil, D.N. Economic Growth, 2nd ed.; Addison Wesley Press: Boston, MA, USA, 2004.

27. Firth, M.; Lin, C.; Liu, P; Wong, S.M.L. Inside the Black Box: Bank Credit Allocation in China's Private Sector. J. Bank. Fin. 2009, 33, 1144-1155

28. Lu, Z.F.; Zhu, J.G.; Zhang, W.N. Bank Discrimination, Holding Bank Ownership, and Economic Consequences: Evidence from China. J. Bank. Fin. 2012, 36, 341-354.

29. Zhang, J.; Wu, G.Y.; Zhang, J.P. The Estimation of China's Provincial Capital Stock: 1952-2000. Econ. Res. J. 2004, 10, 35-44.

30. Zhang, J.; Shi, S.H. Changes of Total Factor Productivity in China: 1952-1998. World Econ. For. 2003, 2, 17-24.

31. Rodrik, D.; Subramanian, A.; Trebbi, F. Institutions Rule: The Primacy of Institutions over Geography and Integration in Economic Development. J. Econ. Gro. 2004, 9, 131-165.

32. Dawson, J.W. Institution, Investment and Growth: New Cross-Country and Panel Data Evidence. Econ. Inq. 1998, 10, 603-619.

33. Baum, M.A.; David, A.L. The Political Economy of Growth: Democracy and Human Capital. Am. J. Polit. Sci. 2003, 47, 333-347.

34. Doucouliagos, H.; Ulubasoglu, M.A. Democracy and Economic Growth: A Meta-Analysis. Am. J. Polit. Sci. 2008, 52, 61-83.

35. Thompson, M.A.; Rushing, F.W. An Empirical Analysis of the Impact of Patent Protection on Economic Growth. J. Econ. Dev. 1996, 21, 61-79.

36. Thompson, M.A.; Rushing, F.W. An Empirical Analysis of the Impact of Patent Protection on Economic Growth: An Extension. J. Econ. Dev. 1999, 24, 67-76.

37. Zhang, H.; Wang, Y.Q. Governance and Economic Growth: Evolution of the Relationship between Different Income Stages. Com. Econ. Soc. Sys. 2013, 3, 151-159. 
38. Yu, G.H.; Zhang, H. Adaptive Efficiency and Financial Development in China: The Role of Contracts and Contractual Enforcement. J. Inter. Econ. Law 2008, 11, 459-494.

(C) 2014 by the authors; licensee MDPI, Basel, Switzerland. This article is an open access article distributed under the terms and conditions of the Creative Commons Attribution license (http://creativecommons.org/licenses/by/3.0/) 